ALBERT L. HARRIS

(Appalachian State University, USA)

\title{
Net Neutrality and Its Potential Impact on Free Speech
}

I. INTRODUCTION. For hundreds of years, free speech has basically had a limited range and audience. You could speak and anyone within your voice range could hear what you had to say. Then came the printing press and books. You could write your thoughts and they could be published, but many people did not have access or the ability to read them. Radio, television, and other transmission media widened the potential range of your audience. Your words could be heard or read by people not in your general vicinity. But there were still limitations. People may have had access to your written or spoken words, but they did not understand the language in which the words were printed or transmitted in. Stopping your words from being able to be heard or understood created an impediment to free speech. You could verbalize your thoughts, but many people did not have access to hear them. There were still many barriers to inhibit free speech, including language and the ability of the receiver to find your words in a sea of other writings and recordings.

Now we have the Internet. With the Internet, your ability to communicate your thoughts and ideas transcends almost every barrier of the past - language, distance, and the ability for your words to be found, just to name a few. On the Internet, one can "publish" articles, essays, videos, pictures, blogs, Facebook postings, Tweets, and anything else you can conceive of. If you publish your work in your native language, readers can tell Google to translate it and they have your words and ideas presented in their language. If your content is on many servers, someone can turn off one server and your content is still available on other servers. In Iran in 2009 the government shut down the Internet in the country to eliminate the use of Twitter as a communication media for those protesting the results of the presidential election. In Egypt in 2011, the government shut down the Internet to eliminate Facebook, because Facebook was being used to announce the time and place of anti-government rallies. These actions to shut down the Internet were obvious assaults on free speech. 
In both instances, protesters found alternative ways to access the Internet. Now, there seems to be other barriers to the use of the Internet as a conduit of free speech from governments and corporations. These barriers range from governments shutting down the Internet to companies censoring content on the Internet or prioritizing some content over other content.

II. WHAT IS NET NEUTRALITY? So, what is Net Neutrality? It is the principle that Internet service providers and governments should enable access to all legal content and applications regardless of the source, and without favoring or blocking particular products or websites. Put another way, it is not discriminating or charging differentially by user, content, site, platform, application, type of attached equipment, or mode of communication. (Net Neutrality, 2016) Net neutrality is often called the "open Internet."

Why is the concept of net neutrality important? Computer scientists at Microsoft have shown that people will visit a website less often if it is slower than a rival site by more than 250 milliseconds. (Lohr, 2012) That's a blink of the eye. The absence of net neutrality means that internet service providers will have the power to slow down certain types of traffic and, in effect, limit freedom of speech rights since many users do not wait for slow Internet sites or will not return to slow websites. For that reason, internet service providers and governments should not have the legal ability to degrade or block any legal content.

This brings me to my final point regarding net neutrality, which is delivering Internet service is a zero-sum game. (Karr, 2013) The Internet has just so much capacity (routers, bandwidth) at any one time. If a router speeds up service for one user, all other users are automatically slowed down. Speeding up one customer's traffic, say a customer that can pay more or will pay for the privilege of getting faster service, means slowing down someone else's traffic. This is contrary to a neutral net.

III. ARGUMENTS FOR NET NEUTRALITY. This section summarizes some of the arguments for net neutrality. This is not meant to be an allinclusive list nor is it meant to be a thorough discussion of each argument. It is provided as an introduction to some of the arguments for net neutrality.

\section{Digital Rights and Freedoms}

The first argument is that net neutrality preserves digital rights and freedoms. Proponents of net neutrality argue that a neutral net will foster free speech and lead to further democratic participation on the internet. Senator Al Franken from Minnesota fears that without new regulations, the major Inter- 
net Service Providers will use their position of power to stifle people's rights. He calls net neutrality the "First Amendment issue of our time." (Franken, 2010; Hattem, 2014) Proponents of net neutrality wish to prevent the need to pay for speech and the further centralization of media power by ensuring that all people and websites have equal access to each other, regardless of their ability to pay.

\section{Movement of Data}

The second argument for net neutrality deals with controlling the movement of data over the Internet. Some people say cable and telecommunications companies want the role of gatekeepers, being able to control which websites load quickly, load slowly, or don't load at all. These companies want, so the argument goes, to create advantages for their own search engines, Internet phone services, and streaming video services and slowing access or blocking access to those of competitors. By controlling the movement of data over the Internet they are violating the concept of net neutrality.

\section{Preserving Internet Standards}

Dynamic Platform Standards Project has proposed the "Internet Platform for Innovation Act." (http://apps.fcc.gov/ecfs/document/view?id=6519529455) The proposed legislation addresses application layer and the transmission or IP layer of the Internet. It suggests that authorizing incumbent network providers to override either layer separately on the Internet would signal the decline of fundamental Internet standards and international consensus authority. Further, the legislation asserts that bit-shaping the transport of application data will undermine the transport layer's designed flexibility.

\section{Innovation and Competition}

The concept of net neutrality impacts innovation and competition. Net neutrality advocates argue that allowing Internet Service Providers (ISPs) the right to demand a toll to guarantee quality or premium delivery would create an exploitative business model based on the ISPs position as gatekeepers. They warn that by charging websites for access, network owners may be able to block competitor Web sites and services, as well as refuse access to those unable to pay. Proponents of net neutrality argue that allowing for preferential treatment of Internet traffic, or tiered service, would put newer online companies at a disadvantage and slow innovation in online services. Some suggest that, without network neutrality, the Internet will undergo a transformation from a market ruled by innovation to one ruled by deal-making. Others suggest that net neutrality is a preservation of the way the internet has always operated, where the quality of websites and services determined whether they succeeded or failed, rather than deals with ISPs. 


\section{User Intolerance}

As mentioned earlier in this paper, user intolerance for slow-loading sites discourages some users from accessing certain websites. A "fast lane" in the Internet can decrease the user's tolerance to the relative slowness of the "slow lane". Research has shown that users with faster Internet connectivity (e.g., fiber) abandon a slow-loading video at a faster rate than users with slower Internet connectivity (e.g., cable or mobile). (Krishnan and Sitaraman, 2012) Their research studied the patience level of millions of Internet video users who waited for a slow-loading video to start playing. Users who had a faster Internet connectivity, such as fiber-to-the-home, demonstrated less patience and abandoned their videos sooner than similar users with slower Internet connectivity. The results demonstrate how users can get accustomed to faster Internet connectivity, leading to higher expectation of Internet speed, and lower tolerance for any delay that occurs.

\section{End-to-end principle}

Some advocates say network neutrality is needed in order to maintain the end-to-end principle. The end-to-end principle states that in a general-purpose network, application-specific functions ought to reside in the end hosts of a network rather than in intermediary nodes, provided that they can be implemented "completely and correctly" in the end hosts. (End-to-end Principle, 2016) According to net neutrality concepts, all content must be treated the same and must move at the same speed in order for net neutrality to be true. It is this simple but brilliant end-to-end aspect that has allowed the Internet to act as a powerful force for economic and social good. Under this principle, a neutral network is a dumb network, merely passing packets regardless of the applications they support. The data would be in control, telling the network where it should be sent. End-user devices would then be allowed to behave flexibly, as bits would essentially be free and there would be no assumption that the data is of a single data rate or data type.

IV. ARGUMENTS AGAINST NET NEUTRALITY. This section summarizes some of the arguments against net neutrality. As with the previous section, this is not meant to be an all-inclusive list nor is it meant to be a thorough discussion of each argument. It is provided as an introduction to some of the arguments against net neutrality.

\section{Investments in Broadband Infrastructure}

Companies invest in things that will potentially add to their wealth. Internet rules that allow them to increase revenue by "adjusting" broadband fees and speeds will also allow them to invest more in the Internet and broadband 
technology. This investment, so the argument goes, means that the billions of dollars invested in broadband investment will multiply across the entire economy. The argument also asserts that the absence of this investment will lead to a slowdown, if not a hold, in broadband expansion. Opponents of net neutrality also argue that prioritization of bandwidth is necessary for future innovation on the Internet. Telecommunications providers such as telephone and cable companies, and some technology companies that supply networking gear, argue telecom providers should have the ability to provide preferential treatment in the form of tiered services, by giving online companies willing to pay more the ability to transfer their data packets faster than other Internet traffic. (Sadik, 2007) The added revenue from such services could be used to pay for the building of increased broadband access for more consumers.

\section{Broadband Choice}

Because of competition, nearly every American can choose from a minimum of 5-6 broadband internet service providers, despite claims that there are only a 'small number' of broadband providers. (Ehrlich, 2014) Citing research from the FCC, Ehrlich wrote that 90 percent of American households have access to at least one wired and one wireless broadband provider at speeds of at least $4 \mathrm{Mbit} / \mathrm{s}$ downstream and $1 \mathrm{Mbit} / \mathrm{s}$ upstream and that nearly 88 percent of Americans can choose from at least two wired providers of broadband disregarding speed (typically choosing between a cable and telco offering). Further, three of the four national wireless companies report that they offer 4G LTE to between 250-300 million Americans, with the fourth (T-Mobile) sitting at 209 million and counting. (Ehrlich, 2014) So, the argument goes, there is plenty of choice for users.

\section{Significant and growing competition}

There seems to be growing competition among broadband access providers and few significant competitive problems have been observed to date, anti-net neutrality proponents say. This, suggests that there is no compelling competitive rationale for net neutrality regulations. One study found that "Between mid-2002 and mid-2008, the number of high-speed broadband access lines in the United States grew from 16 million to nearly 133 million, and the number of residential broadband lines grew from 14 million to nearly 80 million. Internet traffic roughly tripled between 2007 and 2009. At the same time, prices for broadband Internet access services have fallen sharply." (Becker, et, al, 2010)

\section{Potentially increased taxes}

Another argument for those who opposed the net neutrality ruling is that current U.S. legislation would reclassify broadband access as a Title II service 
subject to Federal Communications Commission (FCC) regulation. They argue that this would impose similar laws on Internet carriers and the laws and regulations would explicitly open the door to billions of dollars in new fees and taxes on broadband by subjecting them to the telephone-style taxes under the Universal Service Fund. Exactly how much tax would be added, no one knows. Wood (2014) stated that under favorable circumstances, "the increase would be exactly zero." Anti-net neutrality proponents say that any new taxes will mean higher prices for consumers and more hidden fees that they have to pay.

\section{Prevent overuse of bandwidth}

Since the early 1990s, Internet traffic has increased steadily. The arrival of picture-rich websites, such as Netflix, Hulu, Amazon Prime, Showtime, HBO, YouTube and a myriad of other services, has exacerbated the problem. Networks were not prepared to handle the amount of data required to run these sites. Anti-net neutrality proponents have argued that net neutrality would prevent broadband networks from being expanded and prevent new networks from being built. This, they say, will limit available bandwidth and thus endanger innovation.

\section{High costs to entry for cable broadband}

According to some anti-net neutrality advocates, local governments and public utilities impose the most significant barriers to entry for more cable broadband competition. Many times, local governments and their public utilities have the final say on whether an ISP can build a network. It is public officials that many times determine what hoops an ISP must jump through to get approval for access to publicly owned "rights of way" in which to place their fiber optic cables and wires. This can result in municipal requirements for ISPs such as building out of their service area, or in places that where it is not a demanded, or donating equipment or delivering free broadband to government buildings.

\section{Unnecessary regulations}

Opponents of new U.S. net neutrality policies point to the success of the internet as a sign that new regulations are not necessary. They argue that the freedom which websites, ISPs and consumers have had to settle their own disputes and compete through innovation is the reason why the internet has been unsuccessful. In regulating how the internet is provided, opponents argue that the government will hinder innovation on the web. 
V. METHODS THAT VIOLATE THE CONCEPT OF NET NEUTRALITY. Discrimination by protocol, or bandwidth throttling, is the favoring or blocking of information based on aspects of the communications protocol that the computers are using to communicate. Comcast deliberately prevented some subscribers from using peer-to-peer file-sharing services to download large files.

Discrimination by IP address (also called IP address blocking and deep packet inspection) prevents connection between a server or website and certain IP addresses or ranges of addresses. IP address blocking effectively bans less desired connections from hosts stopping or slowing certain affected addresses progress to a website, mail server, or other Internet server. Another form of IP address discrimination is deep packet inspection. It is a form of network packet filtering that examines the data or header parts of a packet as it passes an inspection point, searching for protocol non-compliance, viruses, spam, intrusions, or defined criteria to decide whether the packet may pass or if it needs to be routed to a different destination. Deep packet inspection is often used for Internet censorship. In 2013, French telecom operator Orange, complained that traffic from YouTube and other Google sites made up roughly $50 \%$ of total traffic on the Orange network. They reached a deal with Google, in which they charged Google for the traffic incurred on the Orange network. (Robertson, 2013)

ISPs would love to be able to favor their own private protocols over others. ISPs are able to encourage the use of specific services by utilizing private networks to discriminate what data is moved and how fast. One example is when Comcast struck a deal with Microsoft that allowed users to stream television through the Xfinity app on their Xbox 360s without it affecting its transmission. On the other hand, users that utilized other television streaming apps, such as Hulu, Netflix, or HBO Go, were subject to possible ISP discrimination. Comcast denied that this infringed on net neutrality principles since "it runs its Xfinity for Xbox service on its own, private Internet protocol network." (Mitchell, 2012)

Peering discrimination, or peering, is a voluntary interconnection of separate Internet networks for the purpose of exchanging traffic between the users of each network. When peering, neither party pays the other in association with the exchange of traffic; instead, each derives and retains revenue from its own customers. In 2014, Netflix reached an arrangement with Verizon to improve the quality of its service to Netflix clients. This arrangement was made in response to increasingly slow connection speeds through Comcast over the course of 2013, where average speeds dropped by over $25 \%$ of their values a year before reaching an all-time low. After the deal was struck in January 2014 , the Netflix speed index recorded a $66 \%$ increase in connection. (Net Neutrality, 2016) 
VI. EXAMPLES OF NET NEUTRALITY VIOLATIONS IN NORTH AMERICA. How does blocking particular products or websites or charging differentially by user, content, site, platform, or application impair freedom of speech? Let me give you a few examples from North America, as documented by the ACLU:

Example 1. During a performance by a rock group, AT\&T censored words from one of the songs. What words? "George Bush, leave this world alone" and "George Bush find yourself another home." By censoring those words, AT\&T denied viewers the complete, exclusive coverage they were promised. Although the words contained no profanity, an AT\&T spokesperson claimed that the words were censored to prevent youth visiting the website from being exposed to "excessive profanity." Selective censorship because someone or some corporation does not like or agree with the message is just plain censorship. (What is Net Neutrality?)

Example 2. Comcast, the United States' largest cable TV operator and second largest Internet Service Provider, used a technique called "deep packet inspection" to find and block file transfers from customers using popular peer-to-peer networks. These actions were confirmed in nationwide tests conducted by the Associated Press and took place at times when the network was not congested. The action blocked some illegal copying of copyright or pirated material, but also blocked anyone using the peer-to-peer network for legitimate purposes. In effect, this action discriminated against an entire class of perfectly legal and legitimate online activities. (What is Net Neutrality?)

Example 3. Verizon Wireless cut off access to a text-messaging service used by a pro-abortion-rights group. The group used the text-messaging service to send messages to its supporters. Verizon stated it would not service programs from any group "that seeks to promote an agenda or distribute content that, in its discretion, may be seen as controversial or unsavory to any of our users." In other words, someone at Verizon Wireless did not like the message, so they eliminated the group's ability to transmit their message. (What is Net Neutrality?)

Example 4. A Canadian telecommunications company, involved in a bitter labor dispute, blocked its Internet subscribers from accessing a website run by the union that was on strike against the telecommunications company. (What is Net Neutrality?)

These were all clear violations of the concept of net neutrality and resulted in a restriction of free speech. However, most countries where free speech is not a basic right have seen the Internet shut down completely or heavily cen- 
sored concerning which applications are available. These countries include the Eritrea, North Korea, Saudi Arabia, Ethiopia, Vietnam, Iran, China, the Maldives, Nepal, Burma or Myanmar as it is now called, Syria, and Libya, just to name a few.

VII. NET NEUTRALITY AND THE EUROPEAN UNION. Similar actions have been taken in Europe. In 2014, the Turkish Prime Minister shut down Twitter and YouTube and threatened to ban Facebook after they exposed corruption within the government. (Rawlinson, 2014) The Prime Minister cited four court orders as the basis for blocking Twitter and YouTube, where some users posted voice recordings and documents purportedly showing evidence of corruption among the Prime Minister's inner circle. Turkish internet users were quick to devise ways to circumvent the block. The top trending hashtag globally quickly became \#TwitterisblockedinTurkey. The disruption sparked a virtual uproar with many people around the world comparing Turkey to Iran and North Korea, where social media platforms are tightly controlled. Some users called for calm to see what would happen, while others called for street protests. Turkey decided to lift the ban on Twitter and YouTube in the late afternoon after the companies agreed to remove all images of the prosecutor and abide by the Turkish court orders and after authorities verified that they had done so.

Even in 2016, the EU is struggling with net neutrality. Plans under consideration now in the European Parliment, would require telecommunications companies and Internet Service Providers to ensure the "equal treatment of all traffic" except in certain circumstances. These range from having to comply with a request from law enforcement, preserving the security of a network, or letting users introduce parental controls. However, thanks to powerful business lobbies, the telecommunication operators will be able to offer specialized, faster services so long as they do not interfere with the service offered to other customers. (Baraniuk, 2015; Hern, 2015; Temperton \& Burgess, 2015)

Meanwhile, in January 2016, the Council of Europe, an international organization focused on promoting democracy, rule of law, human rights, economic development and standardization of certain regulatory functions in $\mathrm{Eu}-$ rope, defined its version of net neutrality by stating "Internet traffic should be treated equally, without discrimination, restriction or interference irrespective of the sender, receiver, content, application, service or device." ("Recommendation CM/Rec(2016)1 of the Committee of Ministers. . . 2016) The council said that there should be no interference with data traffic flowing across the internet. The only exceptions they made were for traffic management, network security or a court order. One reporter commented that "the wording is precise, strong and unambiguous.” (McCarthy, 2016) 
VIII. CONCLUSION. Net neutrality is not a technical issue, it is more of a political and a moral issue. The Internet has become the principal medium through which we express ourselves and access information. The Web is now our debate hall, our printing press, our information delivery service, and the source of much of our information. Most of us, and especially those under 30 years old, rely on an open Internet to collaborate and to usher our culture into the future. Can net neutrality potentially impact the concept of free speech? The answer to that question is YES. Some proponents of Net Neutrality say it is possibly the most important freedom of speech issue of our time with global implications.

\section{BIBLIOGRAPHY}

Baraniuk, Chris (2015) "European Parliament votes against net neutrality amendments" BBC, Published: 27/10/2015, Accessed: 21/04/2016, http://www.bbc. com/news/technology-34649067

Becker, Gery S, Dennis W. Carlton, and Hal S. Sider (2010) "Net Neutrality and Consumer Welfare", Journal of Competition Law \& Economics, 6(3), 497-519

Brodkin, Jon (2016) "One year later, net neutrality still faces attacks in court and Congress" Ars Technica, Published: 26/02/2016, Accessed: 21/04/2016. http://arstechnica.com/ business/2016/02/one-year-later-net-neutrality-still-faces-attacks-in-court-and-congress/

Campbell, Fred (2015) "Net neutrality proponents have joined forces with the greatest threat to free speech" The Hill, Published: 29/10/2015, Accessed: 21/04/2016. http:/thehill.com/blogs/congress-blog/technology/258103-net-neutrality-proponents-have-joined-forces-with-the-greatest

Ehrlich, Everett (2014) "The State of U.S. Broadband: Is It Competitive? Are We Falling Behind?" Progressive Policy Institute. Published: 2014, Accessed: 29.04.2016. http://www.progressivepolicy.org/wp-content/uploads/2014/06/2014.06-Ehrlich_ The-State-US-Broadband_Is-it-competitive-are-we-falling-behind.pdf

"End-to-End Principle" (2016) Wikipedia, Published: 04/04/2016, Accessed: 29/04/2016. https://en.wikipedia.org/wiki/End-to-end principle

Finley, Klint (2016) "Net Neutrality Is in More Danger Than Ever" Wired, Published: 01/03/2016, Accessed: 21/04/2016. https://www.wired.com/2016/03/despite-fccnet-neutrality-danger-ever/

Franken, $\mathrm{Al}$ (2010) "Net neutrality is foremost free speech issue of our time" CNN. com, Published: 05/08/2010, Accessed: 21/04/2016. http://edition.cnn.com/2010/ OPINION/08/ 05/franken.net .neutrality/

Green, Alisha (2015) "Battle Over FCC's Net Neutrality Rules May Redefine Free Speech" Truth-Out.org, Published: 05/10/2015, Accessed: 21/04/2016. http:// www.truth-out.org/ news/item/33142-battle-over-fcc-s-net-neutrality-rules-mayredefine-free-speech 
Hattem, Julian (2014) "Franken: Net neutrality is 'First Amendment issue of our time"" The Hill, Published: 08/07/2014, Accessed: 29/04/2016. http://thehill. com/policy/technology/211607-franken-net-neutrality-is-first-amendment-issueof-our-time

Hern, Alex (2015) "EU net neutrality laws fatally undermined by loopholes, critics say" Theguardian, Published: 10/27/2015, Accessed: 21/04/2016. https://www. theguardian. com/technology/2015/oct/27/eu-net-neutrality-laws-fatally-undermined-by-loopholes-critics-say

Karr, Timothy (2013) "The Payola Internet" The Huffington Post, Published: 11/12/2013, Accessed: 29/04/2016. http:/www.huffingtonpost.com/timothy-karr/ the-payola-internet_b_4424457.html

Krishnan, S. Shunmuga and Ramesh K. Sitaraman (2012) "Video Stream Quality Impacts Viewer Behavior: Inferring Causality Using Quasi-Experimental Designs" IMC '12 Proceedings of the 2012 ACM conference on Internet measurement conference, Pg 211-224, The ACM Digital Library

Lohr, Steva (2012) "For Impatient Web Users, an Eye Blink Is Just Too Long to Wait" The New York Times, Published: 29/02/2012, Accessed: 21/04/2016. http://www. nytimes.com/2012/03/01/technology/ impatient-web-users-flee-slow-loading-sites. html? $\mathrm{r}=0$

Macaes, Bruno (2015) "Why net neutrality is a question of free speech" Wired.co.uk, Published: 31/03/2015, Accessed: 21/04/2016. http://www.wired.co.uk/news/archive/2015-03/31/net-neutrality-and-free-speech

Macdowell, Robert M. (2014) "Net Neutrality Vs. Free Speech" Wall Street Journal, Published: 28/08/2014, Accessed: 21/04/2016. http:/www.wsj.com/articles/ robert-m-mcdowell-net-neutrality-vs-free-speech-1409269385

May, Randolph (2012) "Why Net neutrality is incompatible with 'Internet freedom"” CNET, Published: 03/09/2012, Accessed: 21/04/2016. http://www.cnet.com/ news/why-net-neutrality-is-incompatible-with-internet-freedom/

McCarthy, Kieren (2016) "Council of Europe gets tough on net neutrality" The Register, Published: 13/01/2016, Accessed: 21/04/2016. http://www.theregister.co.uk/2016/01/13/council_of_europe_net_neutrality_guidelines/

Miniter, Frank (2014) "Limbaugh is Right, Net Neutrality Is An Attack On Free Speech -- So Why Is Comcast For It?, Forbes, Published: 18/09/2014, Accessed: 21/04/2016. http://www.forbes.com/sites/frankminiter/2014/09/18/limbaugh-is-right-net-neutrality-is-an-attack-on-free-speech-so-why-is-comcast-forit/\#12a4b008241d

Mitchell, Dan (2012) “Is Comcast violating net-neutrality rules?" Fortune, Published: 16/05/2012 Accessed: 20/04/2016. http://fortune.com/2012/05/16/is-comcastviolating-net-neutrality-rules/

"Net Neutrality" (2016) Wikipedia, Published: 23/04/2016, Accessed: 29/04/2016. https://en. wikipedia.org/wiki/Net_neutrality

"Net Neutrality's Impact on Free Speech" (2014) Freepress, Published: 23/06/2014, Accessed: 21/04/2016. http://www.freepress.net/blog/2014/06/23/net-neutralitys -impact-free-speech 
Rawlinson, Kevin (2014) "Turkey blocks use of Twitter after prime minister attacks social media site" The Guardian, Published: 21/03/2014, Accessed: 21/04/2016. http://www.theguardian.com/world/2014/mar/21/turkey-blocks-twitter-primeminister

"Recommendation CM/Rec(2016)1 of the Committee of Ministers to member States on protecting and promoting the right to freedom of expression and the right to private life with regard to network neutrality" (2016) Council of Europe, Committee of Members, Published 13/01/2016, Accessed: 21/04/2016. https:// wcd.coe.int/ViewDoc.jsp?p=\&Ref= CM/Rec\%282016\%291\&Language=lanEnglish $\&$ Ver $=$ original $\&$ BackColorInternet $=\mathrm{C} 3 \mathrm{C} 3 \mathrm{C} 3 \&$ BackColorIntranet $=\mathrm{ED}-$ B021\&BackColorLogged $=$ F5D383\&direct $=$ true

Robertson, Adi (2013) “French ISP Orange says it's making Google pay to send traffic over its network" The Verge, Published: 19/01/2013, Accessed: 20/04/2016. http://www.theverge. com/2013/1/19/3894182/french-isp-orange-says-googlepays-to-send-traffic

Sidak, J. Gregory (2007) "What Is the Network Neutrality Debate Really About?" International Journal of Communication, Vol. 1, 2007, Pg.377-388

Skorup, Brent (2015) "Net Neutrality's Threat to Free Speech,” Mercatus Center, George Mason University, Published: 03/12/2015, Accessed: 21/04/2016. http:// mercatus.org/expert_commentary/net-neutrality-threat-free-speech-fcc-isp

Temperton, James and Burgess, Matt (2015) "European Parliament votes in favour of 'two speed' internet” Wired.co.uk, Published: 27/10/2015, Accessed: 21/04/2016. http://www.wired.co.uk/ news/archive/2015-10/27/net-neutrality-europeanunion-vote

“The 2016 Presidential Candidates' Views on Net Neutrality and Broadband" (2016) Gizmodo, Published: 01/03/2016, Accessed: 21/04/2016. http:/gizmodo.com/ the-2016-presidential-candidates-views-on-net-neutralit-1760829072

"What is Net Neutrality?" American Civil Liberties Union, Published: No date, Accessed: 21/04/2016. https://www.aclu.org/feature/what-net-neutrality

Wood, Matt (2014) "Claims That Real Net Neutrality Would Result in New Internet Tax Skew the Math and Confuse the Law" FreePress, Published: 02/12/2014, Accessed 21/04/2016. http://www.freepress.net/blog/2014/12/02/claims-real-netneutrality-would-result-new-internet-tax-skew-math-and-confuse-law

\section{NEUTRALNOŚĆ SIECI I JEJ POTENCJALNY WPŁYW NA WOLNOŚĆ SŁOWA}

\section{Streszczenie}

Artykuł omawia koncepcję neutralności sieci oraz jej potencjalny wpływ na wolność słowa w czasach kiedy Internet jest medium transmisyjnym. Internet stał się cyfrową autostradą, poprzez którą mamy dostęp do informacji oraz publikujemy nasze 
słowa i zdjęcia. Niektóre z argumentów za i przeciw neutralności sieci są przedstawione, razem z niektórymi metodami używanymi do naruszania konceptu neutralności sieci. Przykłady naruszania neutralności sieci w Ameryce Północnej podkreślają potencjalny wpływ z perspektywy wolności słowa. Na koniec zostaną przedstawione ostatnie wysiłki z zakresu neutralności sieci wewnątrz Unii Europejskiej. Neutralność sieci jest pilną globalną kwestią, która może mieć wpływ na wszystkich ludzi używających Internetu w przyszłości.

\section{LA NEUTRALITÉ DU RÉSEAU ET SON INFLUENCE POTENTIELLE SUR LA LIBERTÉ D’EXPRESSION}

\section{Résumé}

Cet article examine le concept de neutralité du réseau et son influence potentielle sur la liberté d'expression lorsque l'Internet est un média de transmission. L'Internet est devenu une sorte d'autoroute numérique par laquelle nous accédons à des informations et publions nos mots et nos images. Certains parmi les arguments en faveur et contre la neutralité du réseau y sont présentés, ainsi que certaines méthodes utilisées pour violer le concept de neutralité du réseau. Des exemples de violations de la neutralité du réseau en Amérique du Nord mettent en évidence l'influence potentielle de la liberté d'expression. Enfin, les efforts récents concernant la neutralité du réseau au sein de l'Union européenne y sont présentés. La neutralité du réseau constitue un enjeu mondial pressant qui pourrait avoir un impact sur tous ceux qui utiliseront l'Internet à l'avenir. 